\title{
Pengaruh Kinerja Keuangan Dan Makroekonomi Terhadap Harga Saham Sektor Industri Konsumsi
}

\author{
Nur Muflihatun Azizah", ${ }^{1, *}$ Lukytawati Anggraeni ${ }^{2}$, Tony Irawan ${ }^{3}$ \\ Management and Business, Business School, IPB University, Bogor, Indonesia ${ }^{1}$ \\ Department of Economic Science, IPB University, Bogor, Indonesia ${ }^{2,3}$ \\ Email: muflihahazizah@gmail.com (Nur Muflihatun Azizah)
}

\begin{abstract}
Abstrak: Harga saham dapat dipengaruhi oleh kinerja keuangan dan makroekonomi. Investor perlu mempertimbangkan kondisi keuangan dan makroekonomi dalam mengambil keputusan investasi. Tujuan dari penelitian ini mengetahui pengaruh rasio-rasio keuangan dan makreokonomi terhadap harga saham. Metode regresi data panel diaplikasikan untuk menganalisis pengaruh kinerja keuangan dan makroekonomi terhadap harga saham. Hasil regresi menunjukkan rasio likuiditas (CR) memiliki pengaruh signifikan negatif, dan rasio profitabilitas (ROE) signifikan positif mempengaruhi harga saham. Makroekonomi inflasi serta nilai tukar secara signifikan positif mempengaruhi harga saham. Emiten dengan likuiditas yang tinggi perlu memperhatikan dan mengendalikan tingkat likuiditas, karena likuiditas yang tinggi dapat menurunkan harga saham. Investor dapat membandingkan kinerja perusahaan sebelum mengambil keputusan investasi.
\end{abstract}

Keyword: Harga Saham, Sektor Industri Konsumsi, Kinerja Keuangan dan Makroekonomoi.

\begin{abstract}
Stock price can be affected by financial performance and macroeconomic. Investors need to consider financial performance and macroeconomic condition in making investment decision. The goal of this study is to analyze the effect of financial performance and macroeconomic toward stock price of consumer goods industry. Panel Data Regression is used in this study to analyze the effect of financial performance and macroeconomic toward stock price. The result of this study shows the liquidity ratio $(C R)$ has a significant and negative effect toward stock price, while the profitability ratio (ROE) has a significant and positive effect toward stock price. Macroeconomic inflation and exchange rate have a significant and positive effect toward stock price. Firms with high liquidity ratio $(C R)$ have to control the liquidity ratio, because in the long term high liquidity has a negative effect toward stock price so the stock price may decrease. Investors need to compare the financial performance in order to make a good decision.
\end{abstract}

Keyword: Stock price, Consumer goods industry, Financial performance and Macroeconomic.

\section{PENDAHULUAN}

Sektor industri konsumsi merupakan salah satu pilihan menarik untuk investasi saham. Aspek pertama dilihat dari kontirubusi sektor industri barang konsumsi terhadap Produk 
Domestik Bruto (PDB) Indonesia dari 2011-2015 menunjukkan tren peningkatan. Rata-rata kontribusi terhadap PDB Indonesia dari tahun 2011-2015 mencapai 13.2 persen dari total PDB Indonesia. Asepk kedua, dari kapitalisasi pasar yang besar mencapai $22.36 \%$ dari keseluruhan kapitalisasi pasar modal, dengan nilai 1.655 triliun rupiah. Nilai kapitalisasi pasar industri barang konsumsi terbesar kedua setelah sektor keuangan. Kapitalsiasi pasar ini menunjukkan nilai keseluruhan saham perusahaan-perusahaan yang ada di sektor ini. Aspek ketiga, Harga saham industri barang konsumsi dari tahun 2013-2017 menunjukkan pergerakan fluktuatif dengan tren peningkatan. Trend pergerakan saham yang positif menunjukkan pertumbuhan harga saham di masa mendatang.

Tabel 1. Profitabilitas, Likuiditas dan Rasio Hutang Sektor Industri Barang Konsumsi 2012-2017

\begin{tabular}{cccc}
\hline & CR & DER & ROE \\
\hline 2012 & $291.5 \%$ & $34.3 \%$ & $10.8 \%$ \\
\hline 2013 & $273.0 \%$ & $35.3 \%$ & $8.4 \%$ \\
\hline 2014 & $260.6 \%$ & $36.9 \%$ & $8.1 \%$ \\
\hline 2015 & $293.0 \%$ & $37.7 \%$ & $8.4 \%$ \\
\hline 2016 & $299.5 \%$ & $33.8 \%$ & $7.1 \%$ \\
\hline 2017 & $298.7 \%$ & $35.3 \%$ & $7.3 \%$ \\
\hline Rata-rata & $286.0 \%$ & $35.5 \%$ & $8.4 \%$ \\
\hline
\end{tabular}

Sumber: Laporan Keuangan (2012-2017)

Tabel 1 menunjukkan rata-rata profitabilitas (ROE) industri konsumsi menurun pada periode 2012-2017. Profitabilitas rata-rata industri barang konsumsi mencapai $10.8 \%$ pada tahun 2012, penurunan terjadi pada tahun 2013 sebesar $21.9 \%$ menjadi $8.4 \%$, kemudian mengalami penurunan kembali sebesar $4.5 \%$ pada tahun 2014. Profitabilitas sektor ini mengalami pertumbuhan di tahun 2015 sebesar $4.7 \%$ menjadi $8.4 \%$, akan tetapi mengalami penurunan kembali di tahun 2017 sebesar $15.8 \%$ menjadi $7.3 \%$, dan mengalami peningkatan di tahun 2017 sebesar 2\% dengan rata-rata profitabilitas 7.3\%. Hal ini menunjukkan ratarata kinerja keuangan pada sektor industri barang konsumsi mengalami fluktuasi dengan tren penurunan profitabilitas.

Selain profitabilitas rasio hutang menjadi salah satu kinerja keuangan yang penting dalam kinerja perusahaan, pada sektor industri barang konsumsi rasio hutang menunjukkan tren peningkatan pada tahun 2012-2017. Pada tahun 2012 rata-rata rasio hutang industri barang konsumsi mencapai 34.3\%, tahun 2013 mencapai 35.3\%, tahun 2014 mencapai $36.9 \%$, tahun 2015 meningkat $9.9 \%$ dari tahun 2012 mencapai $37.7 \%$. Pada periode 2016 menurun menjadi $33.8 \%$ mengalami penuruan sebesar 10.4\%. Pada tahun 2017 meningkat sebesar $4.4 \%$ dari tahun 2016 sebesar $4.4 \%$ menjadi $35.5 \%$.

Rasio likuiditas sektor industri barang konsumsi dari tahun 2012-2017 memiliki tren peningkatan. Pada tahun 2012 rasio likuiditas sektor barang konsumsi mencapai $291.5 \%$. Pada periode 2013 mengalami penuruan sebesar 6.3\% menjadi $273.0 \%$ dan tahun 2014 kembali menurun $4.4 \%$ menjadi $260.6 \%$. Namun pada periode selanjutnya tahun 2015 rasio likuiditas sektor industri barang konsumsi mengalami peningkatan sebesar 12.4\%, dan 
meningkat $2.2 \%$ di tahun 2016 mencapai likuiditas sebesar 299.5\%, dan mengalami penurunan di tahun 2017 yaitu menurun 0.3\% dibandingkan tahun 2016.

Pasar menyesuaikan informasi perusahaan yang tercermin dalam harga saham, dan rasio keuangan perusahaan memiliki korelasi positif dengan saham di masa depan (Venkates et al., 2012). Investor mempertimbangkan informasi keuangan untuk menentukan strategi fundamental yang baik untuk melakukan investasi. (Cohen et al., 2011) menyatakan bahwa professional dan non-professional investor seringkali menggunakan analisis fundamental ketika mengambil keputusan membeli atau menjual saham. Non-professional investor seringkali menggunakan fundamental tools seperti rekomendasi analis untuk membeli saham dan menggunakan technical tools seperti support and resistence lines untuk menjual saham.

Faktor fundamental dan risiko di luar kendali perusahaan (systemic risk) memiliki pengaruh signifikan terhadap harga saham (Astuty, 2017). Fundamental perusahaan merupakan faktor utama penggerak harga saham (Wira, 2011). Dilihat dari harga saham yang bersifat fluktuatif, dalam jangka panjang akan menggambarkan fundamental perusahaan. Investor yang melakukan kegiatan investasi melihat kinerja perusahaan melalui laporan keuangan. Memahami maksud dari berbagai rasio keuangan perusahaan dan menggunakannya dalam menentukan pembelian atau penjualan saham (Wira, 2011).

Selain faktor internal perusahaan, harga saham dapat dipengaruhi oleh faktor eksternal, hal ini didukung oleh hasil temuan erdahulu. Secara bersama-sama inflasi, suku bunga dan nilai tukar dapat mempengaruhi IHSG, secara parsial makroekonomi inflasi dan nilai tukar mempengaruhi IHSG secara signifikan positif, dan suku bunga dapat mempengaruhi IHSG secara signifikan negatif.

Tujuan penelitian ini berdasarkan latar belakang serta rumusan masalah di atas adalah menganalisis pengaruh faktor internal (kinerja keuangan) dan faktor eksternal (makroekonomi) terhadap harga saham sektor industri konsumsi.

\section{KAJIAN TEORI}

Harga Saham. Harga saham menunjukkan penilaian investor terhadap kinerja perusahaan, perusahaan dengan kinerja yang baik akan berakibat pada apresiasi yang tercermin dari harga saham yang meningkat, dan sebaliknya. Ada beberapa kategori harga saham, yaitu sebagai berikut (Widiatmodjo, 2000): (1) Harga Nominal: harga setiap lembar saham yang tertera pada sertifikat saham merupakan nominal dari setimal saham. Harga nominal biasanya digunakan untuk menentukan dividen untuk setiap lembar saham. (2) Harga Perdana: Harga perdana merupakan harga saham pada saat saham pertama kali tercatat pada Bursa Efek. Harga perdana ditetapkan oleh dua pihak yaitu pihak penjamin emisi (underwriter) dan pihak emiten, sehingga didapatlah harga perdana saham. (3) Harga Pasar: Harga pasar merupakan harga saham yang terbentuk melalui mekanisme penawaran dan pembelian dari seluruh seluruh transaksi di bursa saham. Harga saham menggambarkan kondisi harga pada pasar sekunder, dimana pihak yang terlibat bukan lagi penjamin emisi dan emiten, melaikan investor yang melakukan transaksi penawaran dan pembelian saham.

Faktor Internal (Mikroekonomi). Rasio keuangan digunakan untuk menganalisis dan memonitor kinerja sebuah perusahaan menggunakan metode perhitungan dan pemahaman tentang rasio-rasio keuangan (Gitman, 2006). Rasio keuangan dengan mudah diketahui 
investor melalui kalkulasi data keuangan yang dipublikasikan perusahaan. Basis perhitungan rasio-rasio keuangan diperoleh dari income statement dan balance sheet perusahaan. Sebagai pihak yang bertanggung jawab atas kinerja perusahaan tidak hanya memikirkan kondisi keuangan perusahaan, juga harus memikirkan efek dari kinerja keuangan terhadap penilaian pihak ketiga termasuk investor.

Investor dapat memperoleh informasi kinerja perusahaan melalui rasio-rasio keuangan. Hal ini memudahkan investor dalam melihat kinerja perusahaan secara keseluruhan, dan dapat membantu investor dalam mengambil keputusan investasi. Keputusan investo $r$ seringkali dipengaruhi oleh informasi kinerja keuangan, pergerakan harga saham dalam periode yang relatif singkat dapat memungkinkan investor unutk memperoleh capital gain dari transaksi penjualan dan pembelian saham. Selain itu, investor juga dapat memilih perusahaan yang memiliki histori kinerja keuangan yang dapat memberikan keuntungan berupa dividen kepada investor.

Rasio likuiditas adalah rasio yang menunjukkan kondisi keuangan perusahaan untuk membayar hutang lancarnya (Brigham dan Houston, 2004). Rasio ini memberikan gambaran kemampuan perusahaan dalam membayar utang jangka pendeknya dengan aset lancar seperti kas, persediaan dan piutang (Wira, 2011).

Perusahaan harus menjaga likuiditasnya untuk tetap beroperasi. Likuiditas yang kurang baik akan berdampak pada operasional perusahaan, dan dapat memberikan kerugian. Likuiditas yang positif menandakan aset lancar perusahaan lebih besar dari hutang jangka pendek, dan likuiditas yang negatif menandakan aset lancar perusahaan lebih rendah dibandingkan dengan hutang lancar.

Rasio profitabilitas adalah rasio yang menggambarkan tingkat keuntungan yang diperoleh perusahaan. Profitabilitas perusahaan akan menurun apabila cost of capital perusahaan terlalu tinggi atau penggunaan hutang yang terlalu besar. Profitabilitas juga memberikan gambaran hasil dari beberapa kebijakan dan keputusan yang dilakukan perusahaan selama melakukan operasionalnya (Bringham dan Houston, 2006). Return on asset mengukur seberapa effis ien penggunaan aset perusahaan dengan menghitung return dibandingkan dengan total aset yang digunakan untuk mengasilkan return (Heitger, 2010).

Hutang perusahaan merupakan sejumlah uang pihak ketiga yang digunakan oleh perusahaan untuk mengahasilkan profit. Hutang yang menjadi perhatian penting bagi investor adalah hutang jangka panjang perusahaan, karena perusahaan mempunya kewajiban dan komitmen untuk membayar hutangnya dalam jangka panjang. Perusahaan harus membayar dan memberikan klaim pembayaran hutang kepada pemberi hutang sebelum membagikan keuntungannya kepada shareholder (Gitman, 2006). Semakin besar hutang jangka panjang perusahaan (fixed-cost financing) perusahaan, maka expected risk and return perusahaan semakin besar. Debt to equity ratio merupakan rasio yang menggambarkan jumlah hutang yang dibiayai oleh stockholders (Heitger, 2010).

Faktor Eksternal (Makroekonomi). Nilai tukar merupakam nilai mata uang negara lain dalam mata uang domestik atau rupiah (Suseno, 2018). Untuk memperoleh mata uang asing didapat dengan nilai tertentu dalam mata uang domestik. Di Indonesia sistem nilai tukar dibiarkan bebas tergantung kepada mekanisme pasar, hal ini diberlakukan semenjak tahun 1997.

Inflasi adalah kondisi kenaikan harga barang-barang secara umum dan terus menerus dalam jangka waktu tertentu (Bank Indonesia, 2018). (Case dan Fair, 2002) mendefinisikan 
inflasi sebagai kenaikan tingkat harga keseluruhan. Untuk mengukur inflasi digunakan indikator seperti Indeks Harga Konsumen (IHK), penentuan dari barang dan jasa dalam indikator IHK dengan Survei Biaya Hidup (SBH) oleh Badan Pusat Statistik. (Mankiw et al., 2012) mendefinisikan Indeks Harga Konsumen sebagai keseluruhan biaya barang dan jasa yang dikeluarkan oleh konsumen.

Penelitian (Yuniarti dan Litriani, 2017) menunjukkan bahwa faktor makroekonomi inflasi dan nilai tukar berpengaruh signifikan terhadap harga saham pada sektor industri konsumsi yang terdaftar pada Indeks Saham Syariah. Penelitian oleh (Susanto, 2015) mengenai pengaruh makroekonomi terhadap harga saham menunjukkan bahawa nilai tukar, inflasi dan suku bunga secara bersama-bersama mempengaruhi harga saham. (Mardiyati dan Rosalina, 2013) menganalisis pengaruh makroekonomi terhadap indeks harga saham sektor properti, hasil penelitian menunjukkan bahwa inflasi mempengaruhi secara signifikan positif dan nilai tukar mempengaruhi secara signifikan negatif terhadap indeks harga saham.

Kajian oleh (Mardiyati dan Rosalina, 2013) menganalisis pengaruh makroekonomi terhadap indeks harga sahaam pada sektor Properti, temuan penelitian menunjukkan nilai tukar berpengaruh signifikan negatif terhadap harga saham, sedangkan inflasi dan suku bunga berpengaruh positif namun tidak signifikan.

Kajian Penelitian Terdahulu. Penelitian yang dilakukan (Zulkarnae et al., 2016) menunjukkan bahwa fundamental yang mempengaruhi harga saham pada Sektor Properti di Indonesia adalah retrun on asset (ROA), nett profit margin (NPM), dan total asset turnover (TATO). Faktor Fundamental ROA memiliki faktor yang sangat signifikan dalam mempengaruhi harga saham Sektor Properti di Indoensia. Faktor teknikal yang mempengaruhi harga saham Sektor Properti di Indonesia adalah harga saham sebelumnya.

Penelitian yang dilakukan Hutahaen dan Basith (2017) pada perusahaan makanan dan minuman menunjukkan bahwa fundamental perusahaan yaitu rasio profitabilitas (ROE) dan rasio pasar (EPS) berpengaruh signifikan positif terhadap harga saham pada perusahaan.

Penelitian oleh (Putri, 2015) yang menganalisis pengaruh rasio profitabilitas terhadap harga saham pada perusahaan pertambangan batubara di Indonesia menunjukkan bahwa rasio profitabilitas berpengaruh tidak signifikan terhadap harga saham perusahaan pertambangan batubara di Indoensia.

Penelitian oleh (Purnama dan Purbawangsa, 2017) pada perusahaan pertambangan menunjukan rasio likuditas (CR), rasio hutang (DER), rasio pasar (EPS) dan pertumbuhan PDB memiliki pengaruh yang signifikan positif terhadap harga saham perusahaan pertambangan.

Kajian oleh (Arifin dan Agustami, 2016) terhadap pengaruh kinerja keuangan dan ukuran perusahaan terhadap harga saham sub sektor perkebunan, menunjukkan bahawa rasio likuiditas dan rasio solvabilitas memiliki pengaruh yang negatif terhadap harga saham. Sedangkan rasio profitabilitas, rasio pasar dan ukuran perusahaan memiliki pengaruh yang positif terhadap harga saham.

Penelitian oleh (Sha, 2015) yang melakukan penelitian terhadap pengaruh kebijakan dividen dan kinerja keuangan terhadap harga saham perusahaan manufaktur, temuan penelitian menunjukkan bahwa kebijakan dividen berpengaruh signifikan positif terhadap harga saham perusahaan manufaktur, sedangkan variabel bebas lainnya yaitu likuiditas, 
margin laba bersih (NPM), profitabilitas (ROE) dan rasio harga terhadap nilai buku (PBV) tidak berpengaruh signifikan.

Penelitian oleh (Asmirantho dan Somantri, 2017) pada sub sektor farmasi di Indonesia, hasil penelitian menunjukkan bahwa secara parsial rasio pasar (EPS) berpengaruh signifikan positif terhadap harga saham sektor farmasi. Variabel lainnya CR, ROE, DER, dan TATO tidak berpengaruh signifikan.

Penelitian oleh (Hunjara et al., 2014) tentang pengaruh makroekonomi terhadap harga saham di Pakistan, terdapat hubungan yang kuat antara makroekonomi dan harga saham dalam jangka panjang, dalam jangka pendek tidak ditemukan hubungan yang kuat antara makroekonomi dan harga saham di Pakistan.

Penelitian oleh (Ginting et al., 2016) terhadap pengaruh makroekonomi terhadap harga saham pada sub sektor keuangan di Indonesia. Tingkat suku bunga, kurs dan inflasi berpengaruh terhadap harga saham perbankan di Indonesia, secara simultan suku bunga, kurs dan inflasi berpengaruh terhadap harga saham perbankan. Secara parsial kurs berpengaruh signifikan positif terhadap harga saham perbankan.

Penelitian oleh (Djazuli, 2017) menunjukkan bahwa profitabilitas (ROE) secara signifikan positif berpengaruh terhadap harga saham, sedangkan rasio hutang (DER) berpengaruh negatif signifikan terhadap harga saham perusahaan makanan dan minuman.

\section{METODELOGI}

Variabel dependen pada penelitian ini adalah harga saham industri barang konsumsi, dengan variabel bebas rasio likuiditas (CR), rasio hutang (DER), rasio profitabilitas (ROE), exchange rate (ER) dan inflasi (INF). Jenis data yang digunakan adalah data sekunder. Data keuangan perusahaan bersumber dari website perusahaan dan website Idn Financial, data harga bersumber dari website Yahoo Finance dan Seputar Forex, data makroekonomi dari website Bank Indonesia. Sampel yang memenuhi kriteria adalah 20 perusahaan yang ada di sektor industri barang konsumi, dengan kriteria pemilihan sebagai berikut. (1) Perusahaan tercatat sebagai emiten selama periode 2012-2017. (2) Tidak pernah keluar dari Bursa Efek Indonesia (delisting), saham emiten tidak pernah mengalami suspen perdagangan. (3) Emiten memiliki laporan keuangan triwulan selama periode 2012-2017 secara berkala.

Tabel 2. Jenis dan Sumber Data

\begin{tabular}{l|l}
\hline \multicolumn{1}{c|}{ Jenis data } & \multicolumn{1}{c}{ Sumber Data } \\
\hline Harga saham & Yahoo Finance, Seputar Forex \\
\hline Return on Asset (ROE) & Laporan Keuangan (website perusahaan dan Idn Financial) \\
\hline Currrent Ratio (CR) & Laporan Keuangan (website perusahaan dan Idn Financial) \\
\hline Debt to equity ratio (DER) & Laporan Keuangan (website perusahaan dan Idn Financial) \\
\hline Nilai Tukar (ER) & Website BI \\
\hline Inflasi (INF) & Website BI \\
\hline
\end{tabular}

Penelitian ini menggunakan pendekatan kuantitatif, data dianalisis menggunakan teknik statistik. Seperti yang dikemukakan oleh (Kountur, 2009), bahwa pendekatan kuantitatif merupakan penelitian dimana data atau informasi yang digunakan dianalisis dengan menggunakan teknik statistik. Pendekatan statistik analisis regresi data panel 
digunakan untuk menganalisis pengaruh kinerja keuangan dan makroekonomi terhadap harga saham sektor industri barang konsumsi.

Tabel 3. Spesifikasi Variabel

\begin{tabular}{|c|c|c|c|}
\hline Variabel & Pengukuran & Literatur & Sumber Data \\
\hline $\begin{array}{l}\text { Harga } \\
\text { Saham }\end{array}$ & $\begin{array}{l}\text { Harga Saham Triwulan } \\
\text { (Moving Average) }\end{array}$ & $\begin{array}{l}\text { (Djazuli, 2017), } \\
\text { (Purnama dan } \\
\text { Purbawangsa, 2017) }\end{array}$ & $\begin{array}{l}\text { Yahoofinance.com, } \\
\text { Seputarforex.com }\end{array}$ \\
\hline $\begin{array}{l}\text { Return on } \\
\text { Equity } \\
\text { (ROE) }\end{array}$ & $\frac{\text { Net Income }}{\text { Total Equity }}$ & $\begin{array}{l}\text { (Djazuli, 2017), } \\
\text { (Purnama dan } \\
\text { Purbawangsa, 2017) }\end{array}$ & $\begin{array}{l}\text { laporan keuangan } \\
\text { triwulan }\end{array}$ \\
\hline $\begin{array}{l}\text { Currrent } \\
\text { Ratio }(\mathrm{CR})\end{array}$ & $\frac{\text { Current Asset }}{\text { Current Liabilities }}$ & (Djazuli, 2017) & $\begin{array}{l}\text { laporan keuangan } \\
\text { triwulan }\end{array}$ \\
\hline $\begin{array}{l}\text { Debt to } \\
\text { equity ratio } \\
\text { (DER) }\end{array}$ & $\frac{\text { Total Liabilities }}{\text { Total Equity }}$ & $\begin{array}{l}\text { (Djazuli, 2017), } \\
\text { (Purnama dan } \\
\text { Purbawangsa, 2017) }\end{array}$ & $\begin{array}{l}\text { laporan keuangan } \\
\text { triwulan }\end{array}$ \\
\hline $\begin{array}{l}\text { Nilai Tukar } \\
\text { (ER) }\end{array}$ & $\frac{\text { Kurs Jual }+ \text { Kurs Beli }}{2}$ & $\begin{array}{l}\text { (Purnama dan } \\
\text { Purbawangsa, 2017), } \\
\text { (Hunjara et al., 2014) }\end{array}$ & Bank Indonesia \\
\hline $\begin{array}{l}\text { Inflasi } \\
\text { (INF) }\end{array}$ & Rata-rata inflasi Triwulan & (Hunjara et al., 2014) & Bank Indonesia \\
\hline
\end{tabular}

Untuk menganalisis pengaruh kinerja keuangan dan makroekonomi terhadap harga saham industri barang konsumsi, maka digunakan metode analisis regresi data panel dengan periode penelitian 2012-2017.

Pendekatan dengan Ordinary Lesat Square (OLS) memiliki asumsi intersep dan slope dari persamaan regresi dianggap konstan antar individu dan antar waktu. Model efek tetap mempertimbangkan adanya akibat dari peubah-peubah yang dihilangkan terhadap intersepintersep cross-section dan time series, untuk memungkinkan perubahan intersep maka ditambahkan peubah dummy ke dalam model. Random effect model seringkali disebut dengan error component model, hal ini dikarenakan parameter yang berbeda antara individu dam waktu dimasukkan ke dalam error. Error individual tidak saling berkolerasi, dan begitupula eror kombinasinya, hal ini merupakan asumsi yang digunakan dalam model random effect (Firdaus, 2012).

Persamaan regresi data panel dalam penelitian ini merujuk pada penelitian sebelumnya seperti (Djazuli, 2017) dan (Purnama dan Purbawangsa, 2017) dan (Hunjara et al., 2014) yang menganalisis hubungan kinerja perusahaan dan makroekonomi dengan harga saham. 


$$
Y_{i t}=\alpha+\beta_{1} C R_{1 i t}+\beta_{2} D E R_{2 i t}+\beta_{3} R_{3 i t}+\beta_{4} E_{4 i t}+\beta_{5} I N F_{5 i t}+e_{i t}
$$

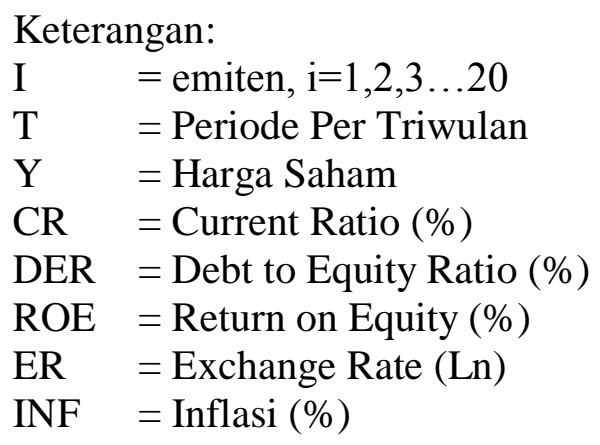

\section{HASIL DAN PEMBAHASAN}

Pemilihan Model. Tahapan pertama dalam regresi data panel dalam penelitian ini adalah tahap pemilihan model terbaik dengan melakukan beberapa uji pemelihan model. Uji chow bertujuan untuk pemilihan model antara model common effect dan model fixed effect dengan menggunakan fixed effect testing dengan memilih redundant fixed effects-lakilihood ratio dengan aplikasi EViews 7. Hasil uji chow dengan nilai probabilitas chi-square 0.000, dapat disimpulkan model terpilih adalah fixed effect model. Uji hausman dilakukan untuk pemilihan model antara fixed effect model dan random effect model dengan random effects testing dan memilih correlated random effects-Hausman test, nilai probabilitas Crosssection random 0.0212 yaitu kurang dari 0.05 artinya metode terbaik yang dipilih adalah fixed effect mode.

Uji Asumsi Klasik. Tahap selanjutnya setelah pemilihan model adalah tahap uji asumsi klasik terhadap model yang sudah terplih. Uji asumsi normalitas menunjukkan nilai probabilitas jarque-bera 0.00 artinya data tidak menyebar dengan normal. Uji asumsi multikolinieritas menunjukkan bahwa tidak terdapat hubungan yang erat antar variabel, ditunjukkan dari nilai hubungan antar variabel kurang dari 0.8. Hasil uji autokorelasi dengan Durbin-Watson menunjukkan bahwa nilai Durbin-Watson (D) kurang dari nilai batas bawah Durbin-Watson (dL) artinya terdapat autokorelasi positif dan nilai 4-D lebih besar dari batas atas nilai Durbin-Watson, artinya tidak terdapat autokorelasi negatif. Hasil uji asumsi heteroskedastisitas menunjukkan bahwa dari nilai probabilitas masing-masing variabel bahwa varibel inflasi (INF) memiliki nilai dibawah 0.05 artinya asumsi heterokedastisitas belum terpenuhi.

Untuk mengatasi asumsi yang belum terpenuhi maka dilakukan pembobotan terhadap model yang telah dipilih dengan pembobotan Cross-section SUR. Hasil pembobotan pada fixed effect model dilakukan pengujian asumsi kembali. Hasil uji normalitas setelah dilakukan pembobotan pada model menunjukkan nilai probabilitas jarque-bera sebesar 0.691 lebih besar dari 0.05 artinya model telah memenuhi asumsi normalitas. Hasil uji multikolinearitas menunjukkan tidak terdapat hubungan yang erat antar variabel yang ditunjukkan pada nilai hubungan antar variabel bebas kurang dari 0.08. Hasil uji autokorelasi menunjukkan bahwa niali Durbin-Watson (D) lebih besar dari batas bawah 
nilai Durbin-Watson artinya tidak terdapat autokorelasi positif, dan nilai 4-D lebih besar dari batas atas nilai Durbin-Watson artinya tidak ada korelasi negatif.

\section{DISKUSI}

Hasil regresi data panel menunjukkan bahwa kinerja keuangan dan makroekonomi memiliki pengaruh signifikan terhadap harga saham industri barang konsumsi dengan taraf nyata 5 persen.

Tabel 6. Determinan Harga Saham Sektor Industri Barang Konsumsi

\begin{tabular}{l|l|l}
\hline \multicolumn{1}{c|}{ Variabel } & \multicolumn{1}{c}{ Coefficient } & Prob \\
\hline C & 1.546 & 0.0000 \\
\hline CR & $-0.004^{* *}$ & 0.0000 \\
\hline DER & 0.002 & 0.7109 \\
\hline ROE & $0.096^{* *}$ & 0.0000 \\
\hline ER & $0.410^{* *}$ & 0.0000 \\
\hline INF & $0.286^{* *}$ & 0.0000 \\
\hline R-squared & 0.99 & \\
\hline Adjusted R-squared & 0.99 & \\
\hline S.E. of regression & 1.025 & \\
\hline F-statistic & 54885 & \\
\hline Prob(F-statistic) & 0.000 & \\
\hline K & &
\end{tabular}

Keterangan:

$(* *)$ : Signifikan pada taraf $5 \%$

Pengaruh Kinerja Keuangan dan Makroekonomi terhada Harga Saham Sektor Industri Barang Konsumsi. Hasil regresi menunjukkan bahwa rasio likuiditas (CR) memiliki pengaruh signifikan negatif terhadap harga saham. Hasil temuan didukung oleh penelitian (Arifin dan Agustami, 2016) yang menunjukkan likuiditas berpengaruh signifikan negatif terhadap harga saham. Kenaikan $1 \%$ CR akan menurunkan harga saham sebesar $0.004 \%$. Kenaikan CR akan menurunkan permintaan investor terahadap saham sehingga harga saham turun, dan sebaliknya. 
Gambar 1. Current Ratio (CR) 2012-2017

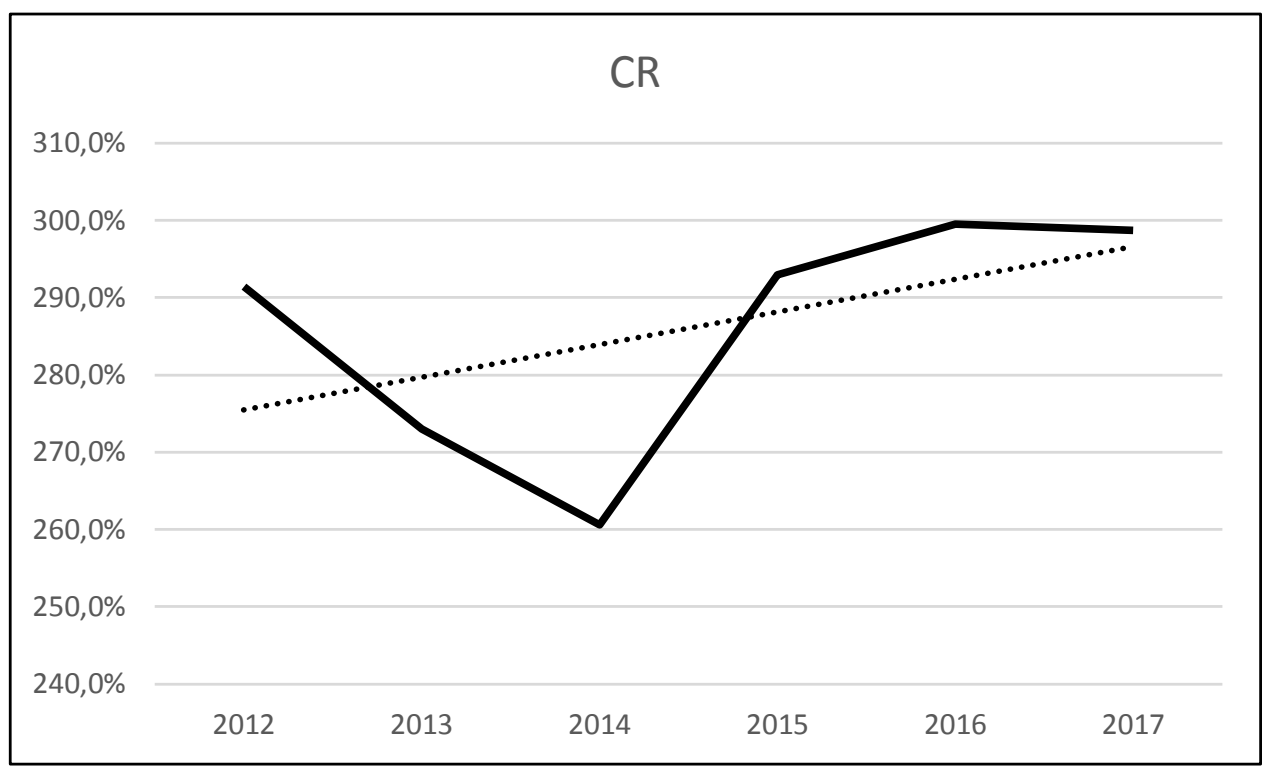

Sumber: Laporan Keuangan 2012-2017 (Data Diolah)

Gambar 1 menunjukkan tren likuiditas (CR) sektor industri barang konsumsi periode 2012-2017 yang memiliki tren peningkatan likuiditas. Dari hasil temuan, likuiditas berpengaruh signifikan negatif terhadap harga saham, dengan tren peningkatan likuiditas maka akan menurunkan harga saham di masa yang akan datang. Perusahaan dengan likuiditas yang tinggi diharapkan dapat mengendalikan tingkat likuiditasnya agar harga saham perusahaan tidak turun.

Profitabilitas (ROE) memiliki pengaruh signifikan positif terhadap harga saham, temuan ini sesuai dengan hipotesis penelitian dan didukung oleh temuan (Dzajuli, 2017) yaitu ROE berpengaruh signifikan positif terhadap harga saham, perusahaan yang menghasilkan keuntungan yang lebih besar dan lebih optimal menggunakan asetnya dalam menghasilkan profit akan lebih menarik minat investor. Kenaikan 1\% ROE akan meningkatkan $9.6 \%$ harga saham. Peningkatan profitabilitas perusahaan menyebabkan permintaan investor terhadap saham meningkat dan harga saham pun terapresiasi. 
Gambar 2. Return on Equity (ROE) 2012-2017

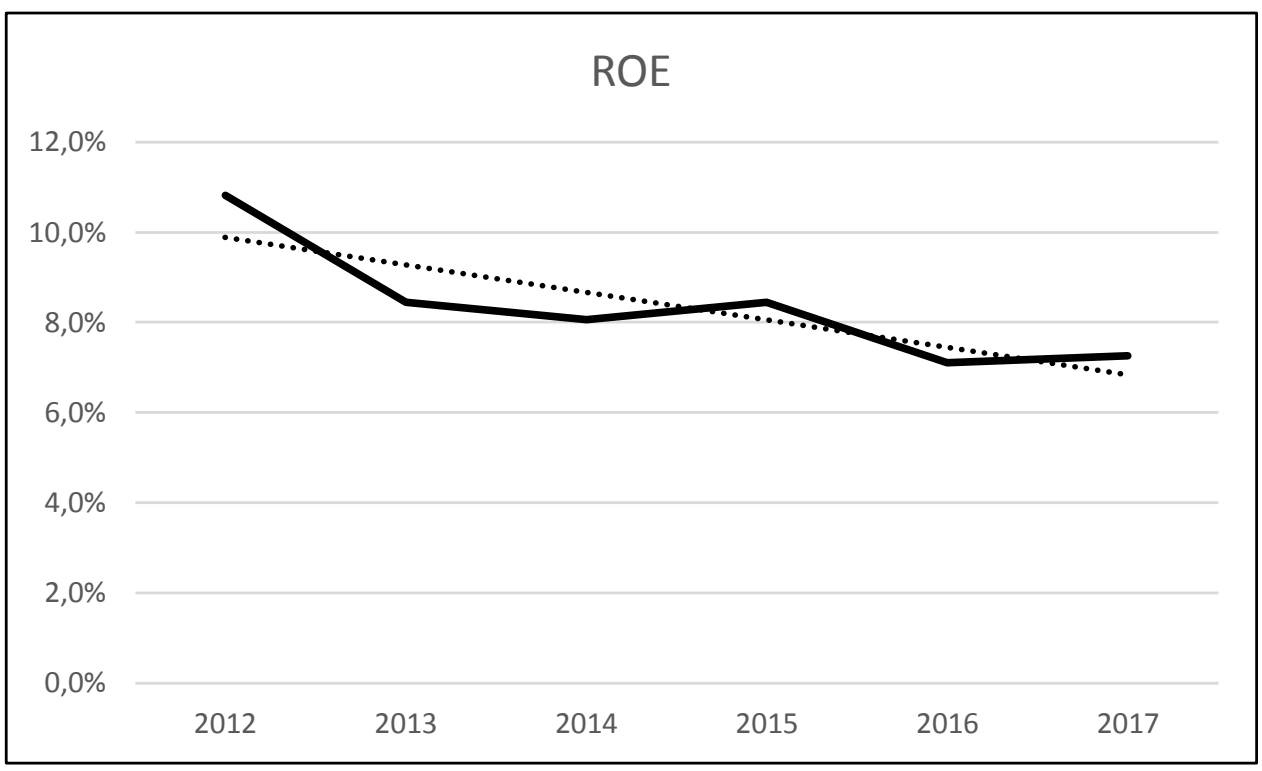

Sumber: Laporan Keuangan 2012-2017 (Data Diolah)

Profitabilitas sektor industri barang konsumsi selama periode 2012-2017 ditunjukkan pada Gambar 2 dengan tren penurunan profitabilitas. Penurunan profitabilitas akan menurunkan harga saham perusahaan, sehingga hal ini harus diperhatikan oleh perusahaan. Investor akan lebih tertarik melakukan investasi pada perusahaan yang memiliki pertumbuhan profitabilitas yang positif, hal ini didukung dengan hasil temuan yang menunjukkan bahwa profitabilitas berpengaruh positif terhadap harga saham. Oleh karena itu perusahaan yang ada di sektor industri konsumsi perlu memperhatikan tingkat pertumbuhan profitabilitas agar terus meningkat.

Nilai tukar (ER) memiliki pengaruh signifikan positif terhadap harga saham, temuan ini didukung oleh (Ginting et al., 2016) yang menyatakan bahwa nilai tukar secara positif signifikan berpengaruh terhadap harga saham. Penguatan nilai rupiah terhadap dolar akan meningkatkan permintaan investor terhadap saham sehingga harga saham naik, dan sebaliknya penurunan nilai tukar rupiah terhadap dolar akan menyebabkan menurunnya permintaan terhadap saham sehingga harga saham turun. Kenaikan $1 \%$ ER akan meningkatkan $42.7 \%$ harga saham sektor industri barang konsumsi, dan sebaliknya penurunan $1 \%$ ER akan menurunkan harga saham sebesar $42.7 \%$.

Nilai tukar rupiah melemah sampai dengan 13850 rupiah per dolar, artinya untuk mendapatkan satu-satuan mata uang dolar harus menukarkan 13850 rupiah per dolarnya. Nilai tukar yang melemah cenderung tidak baik untuk kondisi perusahaan, terutama perusahaan yang mengimpor bahan-bahan produksi yang berdampak pada peningkatan biaya produksi perusahaan. Namun, nilai tukar yang meningkat dapat meningkatkan penjualan bagi perusahaan yang mengekspor produknya. 
Gambar 3. Nilai Tukar Rupiah terhadap Dolar (IDR/USD) periode 2012-2017

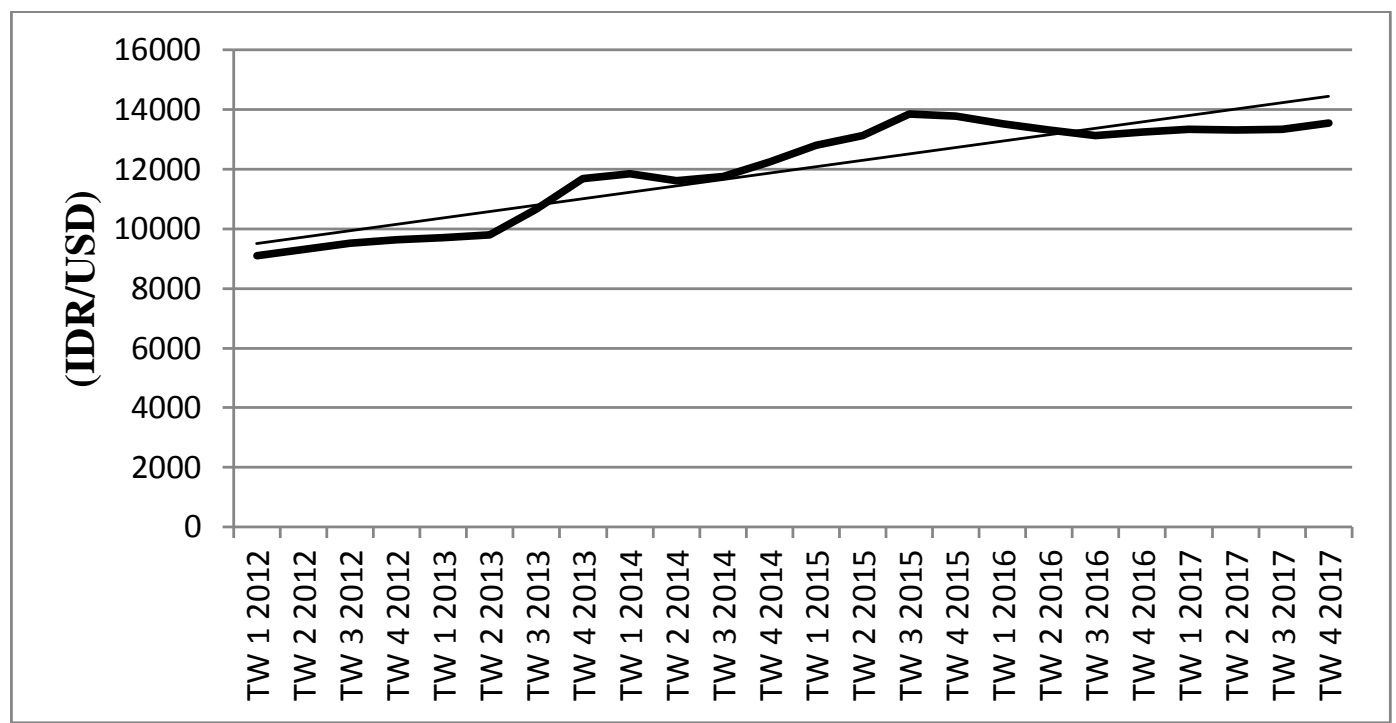

Sumber: Bank Indonesia

Gambar 3 menunjukkan nilai tukar rupiah terhadap dolar (IDR/USD) selama periode 2012-2017. Nilai tukar rata-rata pada masa periode penelitian sebesar 11965.1 rupiah, nilai tukar tertinggi sebesar 13850.88 rupiah yaitu pada kuartal 3 tahun 2015, nilai tukar terendah sebesar 9100.08 yaitu pada kuartal 1 tahun 2012, dan standar deviasi nilai tukar rupiah terhadap dolar sebesar 1622.09. Standar deviasi 1622.09 menggambarkan fluktuasi nilai tukar cukup tinggi pada masa periode penelitian.

Inflasi memiliki pengaruh signifikan positif terhadap harga saham, temuan ini didukung oleh Sukamto (2016) dengan temuan bahwa inflasi berpengaruh signifikan positif terhadap harga saham, karena inflasi ringan dan terkendali berdampak positif bagi perekonomian. Kenaikan 1\% inflasi akan meningkatkan 39.7\% harga saham, kenaikan inflasi menyebabkan permintaan investor terhadap saham meningkat sehingga harga saham terapresiasi. 
Gambar 4. Inflasi Peirode 2012-2017

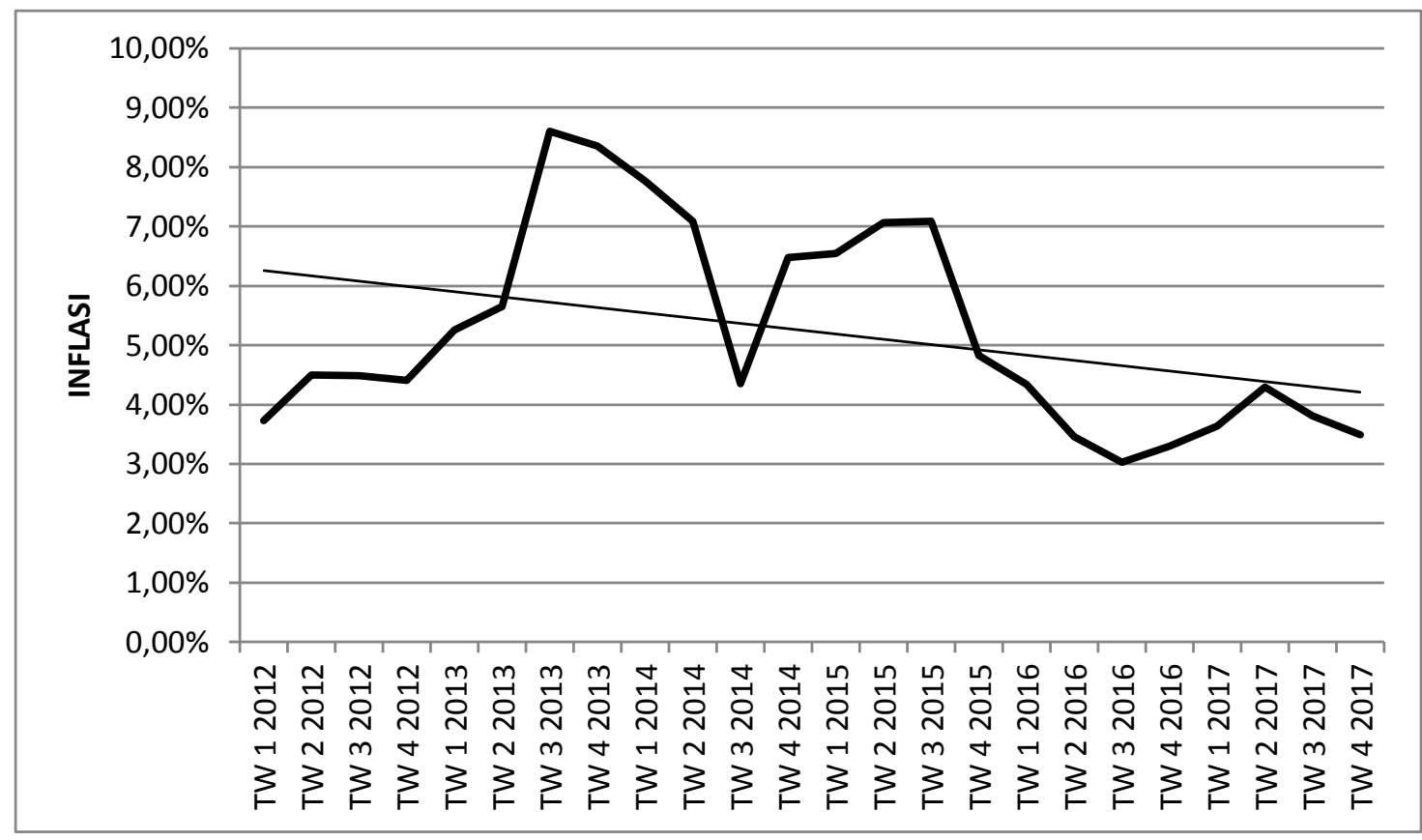

Sumber: Bank Indonesia

Inflasi di indonesia selama periode 2012-2017 ditunjukkan pada Gambar 4. Rata-rata inflasi pada periode penelitian sebesar 5.2\%, inflasi tertinggi sebesar $8.6 \%$, inflasi terendah sebesar 3\%, dan standar deviasi inflasi pada periode penelitian adalah $1.7 \%$. standar deviasi inflasi menunjukkan fluktuasi inflasi yang terjadi pada periode penelitian sebesar $1.7 \%$. Inflasi tertinggi $8.6 \%$ pada periode 3 tahun 2013, dan inflasi terendah $3 \%$ terjadi pada periode 3 tahun 2016. Inflasi di Indonesia periode 2012-2017 menunjukkan tren inflasi yang menurun dan masih terkendali dengan rata-rata inflasi 5.2\%. Investor perlu memperhatikan kondisi makroekonomi sebelum mengambil keputusan investasi.

Implikasi Manajerial. Emiten dengan likuiditas yang tinggi perlu memperhatikan dan mengendalikan tingkat likuiditas perusahaan, karena likuiditas yang tinggi dapat menurunkan harga saham. Emiten dengan profitabilitas dapat meningkatkan kinerja perusahaan dalam menghasilkan profit, dikarenakan kemampuan perusahaan dalam menghasilkan profit meningkatkan harga saham. Emiten dengan profitabilitas yang baik harus mempertahankan dan meningkatkan kinerja perusahaan dalam menghasilkan profit, agar harga saham perusahaan tidak turun dan terus meningkat.

Investor dapat membandingkan kinerja keuangan perusahaan sebelum mengambil keputusan investasi. Emiten dengan profitabilitas (ROE) yang tinggi lebih menarik sebagai tujuan investasi, profitabilitas yang tinggi akan mempengaruhi harga saham secara positif. Emiten dengan likuiditas yang terlalu tinggi memiliki risiko harga saham yang menurun, karena likuiditas yang tinggi dapat menurunkan harga saham. Investor perlu memperhatikan kondisi makroekonomi sebagai pertimbangan pengambilan keputusan. 


\section{KESIMPULAN}

Tujuan penelitian ini adalah menganalisis pengaruh kinerja keuangan dan makroekonomi terhadap harga saham pada sektor industri barang konsumi pada tahun 20122017. Hasil regresi menunjukkan rasio likuiditas (CR) memiliki pengaruh signifikan negatif terhadap harga sahama, profitabilitas (ROE) berpengaruh signifikan positif terhdap harga saham, nilai tukar rupiah terhadap dolar (ER) dan inflasi (INF) berpengaruh signifikan positif terhadap harga saham.

Perusahaan perlu mengendalikan tingkat likuiditasnya agar tidak berdampak negatif terhadap harga saham. Perusahaan diharapkan dapat meningkatkan profitabilitas agar harga saham meningkat, dikarenakan perusahaan dengan profitabilitas yang baik akan lebih menarik minat investor.

Investor dapat membandingkan kinerja keuangan perusahaan, baik dari segi likuiditas ataupun profitabilitas. Perusahaan yang memiliki likuiditas tinggi cenderung memiliki risiko harga saham menurun, sedangkan perusahaan dengan profitabilitas yang tinggi lebih menarik sebagai tujuan investasi karena cenderung memiliki harga saham yang meningkat. Investor perlu memperhatikan kondisi inflasi dan nilai tukar sebagai pertimbangan sebelum mengambil keputusan investasi.

\section{DAFTAR PUSTAKA}

Arifin, N. F., dan Agustami, S. (2016). Pengaruh Likuiditas, Solvabilitas, Profitabilitas, Rasio Pasar, dan Ukuran Perusahaan Terhadap Harga Saham (Studi Pada Perusahaan Subsektor Perkebunan Yang Terdaftar Di Bursa Efek Indonesia Tahun 2010-2014). Jurnal Riset Akuntansi dan Keuangan, 4(3), 1189-1210. https://doi.org/10.17509/jrak.v4i3.4673

Astuty, P. (2017). The influence of fundamental factors and systematic risk to stock prices on companies listed in the Indonesian Stock Exchange. European Research Studies, 20(4A), 230-240.

Asmirantho, E., and Somantri, O. K. (2017). The Effect of Financial Performance on Stock Price at Pharmaceutical Sub-Sector Company Listed in Indonesia Stock Exchange. JIAFE (Jurnal Ilmiah Akuntansi Fakultas Ekonomi), 3(2), 94-107. https://doi.org/10.34204/jiafe.v3i2.778

Bringham, E. F. and J. F. Houston. (2006). Fundamentals of Financial managemen Edisi ke Sebelas, San Diego.: South-Western College.

Bank Indonesia. (2018). Pengenalan Inflasi [Internet]. Diacu 30 Maret 2019. Tersedia pada https://www.bi.go.id/id/moneter/inflasi/pengenalan/Contents/Default.aspx.

Case E, Fair C. 2002. "Prinsip-prinsip Ekonomi Makro". Jakarta (ID): Prenhallindo

Cohen, G., Kudryavtsev, A., and Hon-Snir, S. (2011). Stock market analysis in practice: Is it technical or fundamental?. Journal of Applied Finance and Banking, 1(3), 125138.

Djazuli, A. (2017). The Relevance of Leverage, Profitability, Market Performance, and Macroeconomic to Stock Price. Ekonomi Bisnis, 22(2), 112-122. http://dx.doi.org/10.17977/um042v22i2p112-122

Gitman. (2006). Principles of Managerial Finance, United States of America: Pearson Education, Inc. 
Ginting, M. R. M., dan Sulasmiyati, S. (2016). Pengaruh Tingkat Suku Bunga, Nilai Tukar Dan Inflasi Terhadap Harga Saham (Studi Pada Sub-Sektor Perbankan Di Bursa Efek Indonesia Periode 2011-2015). Jurnal Administrasi Bisnis, 35(2), 77-85.

Mardiyati, U., dan Rosalina, A. (2013). Analisis pengaruh nilai tukar, tingkat suku bunga dan inflasi terhadap indeks harga saham studi kasus pada perusahaan properti yang terdaftar di bursa efek Indonesia. JRMSI-Jurnal Riset Manajemen Sains Indonesia, 4(1), 1-15.

Mowen, M. M., D. R. Hansen, and D. L. Heitger. (2010). Managerial Accounting The Cornerston of Business Decision. Edisi ke Tiga, Boston: Cengage Learning.

Hutahaean, O., dan Basith, A. (2017). Kajian Peramalan dan Pengaruh Profitabilitas terhadap Harga Saham pada Perusahaan Makanan dan Minuman Tahun 2011-2016. Jurnal Manajemen dan Organisasi, 8(1), 75-88.

Hunjra, A. I., Chani, D., Irfan, M., Ijaz, M. S., and Farooq, M. (2014). The impact of macroeconomic variables on stock prices in Pakistan. International Journal of Economics and Empirical Research, 2(1), 13-21.

Kountur, Ronny. (2009). Metode Penelitian. Jakarta: Buana Printing.

Mankiw G, Quah E, Wilson P. 2012. "Pengantar Ekonomi Makro". Jakarta (ID): Salemba Empat.

Puspitaningtyas, Z. (2017). "Is Financial Performance Reflected in Stock Price". Advance in Economics, Business and Management Research 40:17-28. Purnama, I. B. A., \& Purbawangsa, I. B. A. (2017). Pengaruh Kinerja Keuangan dan Variabel Makro Ekonomi terhadap Harga Saham Perusahaan Pertambangan. E-Jurnal Manajemen Universitas Udayana, 6(4), 1729-1760.

Putri, L. P. (2017). Pengaruh Profitabilitas Terhadap Harga Saham Pada Perusahaan Pertambangan Batubara di Indonesia. Jurnal Ilmiah Manajemen dan Bisnis, 16(2), 49-59.

https://doi.org/10.30596/jimb.v16i2.955

Sha, Lie T. (2015). Pengaruh Kebijakan Dividen, Likuiditas, Net Profit Margin, Return On Equity Dan Price To Book Value Terhadap Harga Saham Pada Perusahaan Manufaktur Yang Terdaftar Di Bursa Efek Indonesia 2010-2013. Jurnal Akuntansi 19: 276-294.

Sukamto, S. W. (2018). Pengaruh Inflasi, Suku Bunga, Dan Nilai Tukar RupiahTerhadap Indeks Harga Saham Gabungan (IHSG) Di Bursa Efek Indonesia. Manajemen Bisnis, 6(2), 173-17.

https://doi.org/10.22219/jmb.v6i2.5638

Susanto, B. (2015). Pengaruh Inflasi, Bunga dan Nilai Tukar Terhadap Harga Saham (Studi Pada: Perusahaan Sektor Properti Dan Real Estate Tercatat BEI). Jurnal ASET (Akuntansi Riset), 7(1), 29-38. https://doi.org/10.17509/jaset.v7i1.8858

Suseno, I. (2018). "Sistem dan Kebijakan Nilai Tukar" (Online). Pusat Pendidikan dan Bisnis Studi bank sentral (PPSK). No. 12. Bank Indonesia.

Venkates, C. K., Tyagi, M., \& Ganesh, L. (2012). Fundamental analysis and stock returns: An Indian Evidence. Global Advanced Research Journal of Economics, Accounting and Finance, 1(2), 033-039.

Widoatmodjo S, 2000, Cara Sehat Investasi di Pasar Modal, Jakarta (ID): PT Jurnalida Aksara Grafika. 
Wira, D. (2011). Analisis Fundamental Saham. Indonesia: Penerbit Exceed.

Yuniarti, D., dan Litriani, E. (2017). Pengaruh Inflasi Dan Nilai Tukar Rupiah Terhadap Harga Saham Di Sektor Industri Barang Konsumsi Pada Indeks Saham Syariah Indonesia (Issi) Tahun 2012-2016. I-Finance: a Research Journal on Islamic Finance, 3(1), 31-52.

Zulkarnaen, A. H., Syamsun, M., and Maulana, T. N. A. (2016). Analysis of Fundamental and Technical Factors to Stock Price on Residential Property Sector Companies Listed in Indonesia Stock Exchange. International Journal of Scientific and Research Publications, 6(12), 315-319. 